\title{
KASVUSTON TIHEYDEN JA LÄMPÖTILAN VAIKUTUS JAUHOSAVIKAN (CHENOPODIUM ALBUM L.) JA SEN SADON KEHITTYMISEEN
}

\author{
LeILA-RittTa ERViö \\ Helsingin yliopiston kasvinviljelytieteen laitos
}

Saapunut 12. 12. 1971 EFFECT OF GROWTH DENSITY AND TEMPERATURE ON THE DEVELOP-
MENT AND YIELD OF CHENOPODIUM ALBUM L.

\author{
LeILA-RitTta Erviö
}

Institute of Plant Husbandry, University of Helsinki

\begin{abstract}
Pot experiments with Chenopodium album were carried out in phytotrons and outside in a roofed coolhouse in 1969-70. Number of branches per plant was higher in a sparse than in a dense stand at phytotoron temperature of $12^{\circ} \mathrm{C}$. Leaf area index (LAI) was smaller, leaf area per plant larger in a sparse than in a dense stand. Root and leaf yield as well as total plant weight were larger in a sparse than in a dense stand. Total $C$. album yield per unit area was higher from a dense than from a sparse stand. Growth density and temperature had a notable effect on the shape of the yield curve (Figs. 4-5). Daily yield increase per plant was larger but the increase per unit area smaller in a sparse than in a dense stand. Length of the period vegetative growth of $C$. album was reduced and plant development accelerated at $24^{\circ} \mathrm{C}$. The temperature summations required for the various developmental stages of the plant differed from each other at $24^{\circ} \mathrm{C}$ and $12^{\circ} \mathrm{C}$. In phytotrons at $24^{\circ} \mathrm{C}$ plants matured in 90 days, in the coolhouse $\left(15.4^{\circ} \mathrm{C}\right)$ in 116 days; the corresponding temperature summations were $2160^{\circ}$ and $1837^{\circ}$. LAI at $24^{\circ} \mathrm{C}$ was at its highest during flowering and at $12^{\circ} \mathrm{C}$ just before flowering. The phytotron temperature of $12^{\circ} \mathrm{C}$ increased the weight of roots and leaves as well as the total individual weights of plants at a similar developmental stage. Portions of roots and leaves remained smaller at $24^{\circ} \mathrm{C}$ than at $12^{\circ} \mathrm{C}$. At $12^{\circ} \mathrm{C}$ the most intense growth took place in an earlier stage of plant development than at $15.4^{\circ} \mathrm{C}$ (coolhouse) or $24^{\circ} \mathrm{C}$.
\end{abstract}

Kasviyksilön kasvuun vaikuttavat luontainen kasvupotentiaali ja ympäristötekijät, jotka voivat olla kasvulle suotuisia tai rajoittaa sitä. Ympäristötekijöistä valaistus ja lämpötila vaikuttavat kasvien assimilaatiotehoon ja sen kautta myös kilpailukykyyn. Kullakin kasvilajilla on optimilämpötilansa, jossa assimilaatio tapahtuu voimakkaimmin. Lauhkean ilmaston rikkakasveilla se on yleensä noin $25^{\circ}$ C. (Meyer ja Andersson 1963). Tutkimuksissa, jotka koskevat lämpötilan vaikutusta rikkakasveihin, on pääasiallisesti käsitelty rikkasiementen itämistä (Kolk 1947, BARton 1953, Steinbauer ja Grigsby 
1957). Sen sijaan kirjallisuudesta löytyy vain vähän tietoja lämpötilan vaikutuksesta rikkakasvien kasvamiseen ja kehittymiseen (Scheer 1934, Hull 1958, Jordan ja DAy 1967, HÅKAnsson 1969). Helsingin yliopiston kasvinviljelytieteen laitoksella Viikissä suoritettiin vuosina 1969 - 70 astiakokeita, joissa tutkittiin jauhosavikan (Chenopodium album L.) sadon muodostumista tiheydeltään erilaisissa kasvustoissa kahdessa lämpötilassa.

\section{Tutkimusaineisto ja -menetelmät}

Kokeet järjestettiin kasvinviljelytieteen laitoksen fytotroneissa ja astiakoehallissa. Jauhosavikat kasvatettiin muoviastioissa, joiden pinta-ala oli $200 \mathrm{~cm}^{2}$ ja tilavuus $2 \frac{1}{2}$ litraa. Kasvualustana käytettiin hiekan ja lannoitetun kasvuturpeen seosta suhteessa 1:3. Kasvien runsaasta veden ja ravinteiden saannista huolehdittiin kokeiden kestäessä.

Fytotroneissa suoritetuissa kokeissa jauhosavikat kylvettiin muoviastioihin ja taimien noustua pinnalle harvennettiin kasvutiheyksiin 5 ja $23 \mathrm{kpl} /$ astia, jotka vastasivat 256 ja 1152 yksilöä $/ \mathrm{m}^{2}$. Kerranteita oli neljä. Fytotronien lämpötila säädettiin $24^{\circ}$ ja $12^{\circ} \mathrm{C}$ :ksi ja suhteellinen kosteus $65 \%$ :ksi. Valoisan ajan pituus vuorokaudessa oli 20 tuntia ja valaistuksen voimakkuus kasvien korkeudella 16000 luxia. Kahden viikon kuluttua kylvöstä korjattiin ensimmäinen kasvierä. Sen jälkeen korjuut toistettiin aluksi n. viikon välein, myöhemmin, kun kehitys oli hitaampaa, n. 12 vrk:n välein. Korjuukertoja kertyi kaikkiaan yhdeksän, kun koe lopetettiin kasvien ollessa tuleentuneita $24^{\circ}$ C:ssa (=90 vrk kylvöstä).

Astiakoehallin koetta varten jauhosavikat kylvettiin laatikoihin kasvihuoneeseen. Taimet koulittiin turveruukkuihin $(4 \times 4 \mathrm{~cm})$ ja istutettiin 4-lehtiasteella astiakoehalliin muoviastioihin tiheyksin 2 ja 5 tainta/astia, jotka vastasivat 100 ja 256 yksilöä/m². Kerranteita oli 12. Istutusvaiheessa punnittiin varsiston ja juuriston painot $2 \times 5$ kappaleen erästä. Tämän perusteella voitiin myöhemmin laskea istutuksen jälkeen tapahtunut kasvien painonlisäys. Kasvit korjattiin viidellä kehitysasteella: 1) versoasteella, 2) kukintaasteella, 3) siementen kehittyessä, 4) kasvien kellastuessa ja 5) tuleentuneina.

Korjattaessa punnittiin kasvien kuiva-ainesato sekä määritettiin juuri-, varsi- ja lehtisatojen osuudet. Lisäksi fytotroneissa kasvaneitten jauhosavikoitten lehtiala mitattiin optisella planimetrilla.

\section{Tulokset}

$\mathrm{K}$ a s v i e n k e h i t y s. Fytotroneissa korkea lämpötila lyhensi jauhosavikan vegetatiivisen kasvun aikaa ja joudutti kehitystä. Ensimmäiset kasvulehtiparit kehittyivät kasveihin $24^{\circ} \mathrm{C}$ :n lämpötilassa jo 15 vuorokauden kuluttua kylvöstä, kun ne $12^{\circ} \mathrm{C}$ :ssa muodostuivat vasta 28 vuorokauden kuluttua (taulukko 1). Nuput muodostuivat pääversoon $24^{\circ} \mathrm{C}$ :ssa samanaikaisesti ensimmäisten kasvulehtien kanssa. Sen sijaan $12^{\circ} \mathrm{C}$ :ssa nuppuastetta edelsi taimiasteelta lähtien 53 vuorokauden pituinen vegetatiivisen kasvun kausi.

Kasvit tarvitsivat haarojen muodostumiseen $12^{\circ} \mathrm{C}: s s a$ vain hiukan korkeamman lämpötilasumman kuin $24^{\circ} \mathrm{C}$ :ssa (taulukko 1). Sen sijaan nuppuasteen saavuttamiseen käytetty lämpötilasumma oli $12^{\circ} \mathrm{C}$ :ssa noin 2.5-kertainen ja kukinnan alkamiseen tarvittu noin 2.1-kertainen $24^{\circ}$ C:een verrattuna. Jauhosavikka tuleentui fytotroneissa $24^{\circ}$ C:n lämpötilassa 90 vuorokaudessa saatuaan $2160^{\circ} \mathrm{C}: n$ lämpötilasumman. 
Taulukko 1. Lämpötilan vaikutus jauhosavikan kehittymiseen fytotroneissa.

Table 1. Effect of temperature on development of Chenopodium album in phytotrons.

\begin{tabular}{|c|c|c|c|c|}
\hline \multirow[t]{3}{*}{$\begin{array}{l}\text { Kehitysaste } \\
\text { Stage of development }\end{array}$} & \multicolumn{4}{|c|}{$\begin{array}{l}\text { Lämpötila } \\
\text { Temperature }\end{array}$} \\
\hline & \multicolumn{2}{|c|}{$24^{\circ} \mathrm{C}$} & \multicolumn{2}{|c|}{$12^{\circ} \mathrm{C}$} \\
\hline & $\begin{array}{c}\text { Vrk } \\
\text { kylvöstä } \\
\text { Days from } \\
\text { sowing }\end{array}$ & $\begin{array}{l}\text { Lämpötila- } \\
\text { summa } \\
\text { Temperature } \\
\text { summation }\end{array}$ & $\begin{array}{c}\text { Vrk } \\
\text { kylvöstä } \\
\text { Days from } \\
\text { sowing }\end{array}$ & $\begin{array}{l}\text { Lämpötila- } \\
\text { summa } \\
\text { Temperature } \\
\text { summation }\end{array}$ \\
\hline $\begin{array}{l}\text { Taimistunut } \\
\text { Emerged }\end{array}$ & 4 & 96 & 7 & 84 \\
\hline $\begin{array}{l}\text { Ensimmäiset kasvulehdet kehittyneet } \\
\text { First foliage leaves out }\end{array}$ & 12 & 288 & 28 & 336 \\
\hline $\begin{array}{l}\text { Haarojen kehitys alkanut } \\
\text { Start of branching }\end{array}$ & 20 & 480 & 43 & 516 \\
\hline $\begin{array}{l}\text { Nuppuaste }^{1} \\
\text { Flower bud stage }\end{array}$ & 14 & 336 & 70 & 840 \\
\hline $\begin{array}{l}\text { Kukinta alkanut }{ }^{1} \\
\text { Start of flowering }\end{array}$ & 20 & 480 & 84 & 1008 \\
\hline $\begin{array}{l}\text { Siemenet kehittymässä } \\
\text { Seeds developing }\end{array}$ & 35 & 840 & - & - \\
\hline $\begin{array}{l}\text { Kukinta päättynyt } \\
\text { End of flowering }\end{array}$ & 43 & 1032 & - & - \\
\hline $\begin{array}{l}\text { Siemenet alkaneet varista } \\
\text { First seeds shed }\end{array}$ & 43 & 1032 & - & - \\
\hline $\begin{array}{l}\text { Tuleentunut } \\
\text { Maturity }\end{array}$ & 90 & 2160 & - & - \\
\hline
\end{tabular}

Astiakoehallissa, jossa keskimääräinen lämpötila koeaikana oli $15.4^{\circ} \mathrm{C}$ (vaihtelu 14.0 $16.5^{\circ} \mathrm{C}$ ), nousivat eri kehitysasteisiin tarvitut lämpötilasummat jonkin verran korkeammiksi kuin fytotroneissa $24^{\circ}$ C:n lämpötilassa lukuunottamatta haarojen kehittymis- ja kasvien tuleentumisvaihetta (taulukko 2). Jauhosavikka tuleentui astiakoehallissa 116 vuorokaudessa vastaavan lämpötilasumman ollessa $1837^{\circ} \mathrm{C}$.

$\mathrm{H}$ a a r o j e n 1 u k u mä ä rä. Kasvuston tiheys ja lämpötila eivät yksinään vaikuttaneet merkitsevästi haarojen lukumäärään. Sen sijaan haaroja kehittyi fytotroneissa merkitsevästi enemmän harvan kuin tiheän kasvuston yksilöihin lämpötilan ollessa $12^{\circ} \mathrm{C}$ (vuorovaikutuksen F-arvo 12.0*). Niitä oli harvassa kasvustossa $11.5 \mathrm{kpl}$ ja tiheässä $6.8 \mathrm{kpl}$ yksilöä kohti kokeen päättyessä.

L e h t i e n p in t a - a l a. Fytotroneissa kasvaneitten jauhosavikoitten lehtialaindeksi (LAI) kohosi suuremmaksi tiheässä kuin harvassa kasvustossa kummassakin lämpötilassa (taulukko 3). Sen sijaan lehtiala yksilöä kohti oli huomattavasti pienempi tiheässä kuin harvassa kasvustossa.

Lämpötilan vaikutus jauhosavikan lehtialaindeksin kehitykseen ilmenee kuvasta 1. LAI 
Taulukko 2. Jauhosavikan kehitysasteiden saavuttamiseen kulunut aika ja lämpötilasumma astiakoehallissa.

Table 2. Time and temperature summations required for the various developmental stages of $C$. album grown in coolhouse.

\begin{tabular}{lcc}
\hline $\begin{array}{l}\text { Kehitysaste } \\
\text { Stage of development }\end{array}$ & $\begin{array}{c}\text { Vrk kylvöstä } \\
\text { Days from sowing }\end{array}$ & $\begin{array}{c}\text { Lämpötilasumma } \\
\text { Temperature summation }\end{array}$ \\
\hline $\begin{array}{l}\text { Haarojen kehitys alkanut } \\
\text { Start of branching }\end{array}$ & 32 & 448 \\
$\begin{array}{l}\text { Nuppuaste } \\
\text { Flower bud stage }\end{array}$ & 41 & 574 \\
$\begin{array}{l}\text { Kukinta alkanut } \\
\text { Start of flowering }\end{array}$ & 47 & 696 \\
$\begin{array}{l}\text { Kukinta päättynyt } \\
\text { End of flowering } \\
\text { Siemenet kehittymässä } \\
\text { Seeds developing }\end{array}$ & 67 & 1039 \\
Siemenet alkaneet varista \\
$\begin{array}{l}\text { First seeds shed } \\
\text { Tuleentunut } \\
\text { Maturity }\end{array}$
\end{tabular}

Taulukko 3. Kasvutiheyden ja lämpötilan vaikutus jauhosavikan keskimääräiseen lehtialaindeksiin (LAI) ja lehtien pinta-alaan/yksilö.

Table 3. Effect of growth density and temperature on mean leaf area index $(L A I)$ and leaf area per plant of C. album grown in phytotrons.

\begin{tabular}{lcccc}
\hline $\begin{array}{l}\text { Kasvutiheys } \\
\mathrm{kpl} / \mathrm{m}^{2}\end{array}$ & \multicolumn{2}{c}{ LAI } & \multicolumn{2}{c}{$\begin{array}{c}\text { Lehtiala/yksilö sl. } \\
\text { Relative leaf area/plant }\end{array}$} \\
\cline { 2 - 5 } Growth density plants $/ \mathrm{m}^{2}$ & $24^{\circ} \mathrm{C}$ & $12^{\circ} \mathrm{C}$ & $24^{\circ} \mathrm{C}$ & $12^{\circ} \mathrm{C}$ \\
\hline 256 & 0.37 & 2.81 & $15 \mathrm{~cm}^{2}=100$ & 747 \\
1152 & 0.91 & 3.50 & 53 & 200 \\
Tiheyden F-arvot & $106.7^{* * *}$ & $684.0^{* * *}$ & & $67.0^{* * *}$ \\
F-values for density & & & &
\end{tabular}

kasvoi $24^{\circ} \mathrm{C}$ :ssa versoasteelta lähtien kukinta-asteen puoliväliin saakka (= 24 vrk ensimmäisten kasvulehtien muodostumisesta), jonka jälkeen se alkoi pienentyä lehtien kuivumisen vuoksi. Lämpötilan ollessa $12^{\circ} \mathrm{C}$ LAI nousi jo versoasteella, mutta nousu hidastui voimakkaasti noin viisi vuorokautta ennen kukinnan alkamista $(=51$ vrk kasvulehtien ilmaantumisesta). LAI ja lehtiala yksilöä kohti (taulukko 3 ) kehittyivät huomattavasti suuremmiksi $12^{\circ} \mathrm{C}: n$ kuin $24^{\circ} \mathrm{C}: n$ lämpötilassa.

Yksilönpainot. Ju u riston paino yksilöä kohti oli fytotroneissa kasvien samalla kehitysasteella suurempi harvassa kuin tiheässä kasvustossa ja myös suurempi $12^{\circ} \mathrm{C}: n$ kuin $24^{\circ} \mathrm{C}: n$ lämpötilassa, kuten oheiset suhdeluvut jauhosavikan kukintavaiheessa osoittavat:

$\begin{array}{rrr}\text { Kasvutiheys } & 24^{\circ} \mathrm{C} & 12^{\circ} \mathrm{C} \\ 256 \mathrm{kpl} / \mathrm{m}^{2} & 6 \mathrm{mg}=100 & 3700 \\ 1152 \Longrightarrow & 33 & 1050\end{array}$




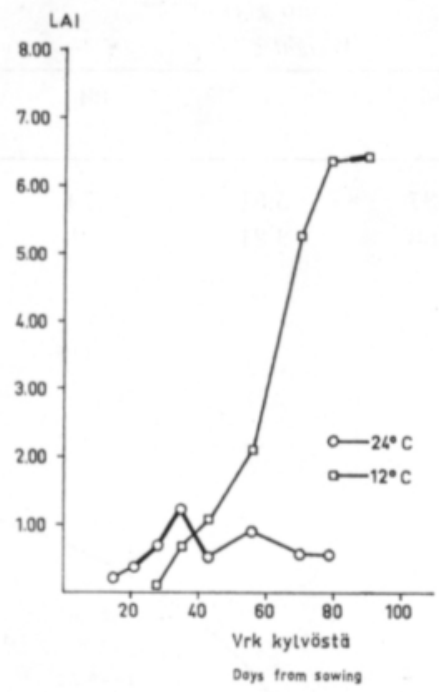

Kuva 1. Jauhosavikan lehtialaindeksin (LAI) kehitys fytotroneissa. Kukinnan ajankohta on merkitty kuvaajiin paksunnoksella.

Fig. 1. Leaf area index (LAI) in C. album grown in phytotrons. Heavy line indicates the date of flowering.

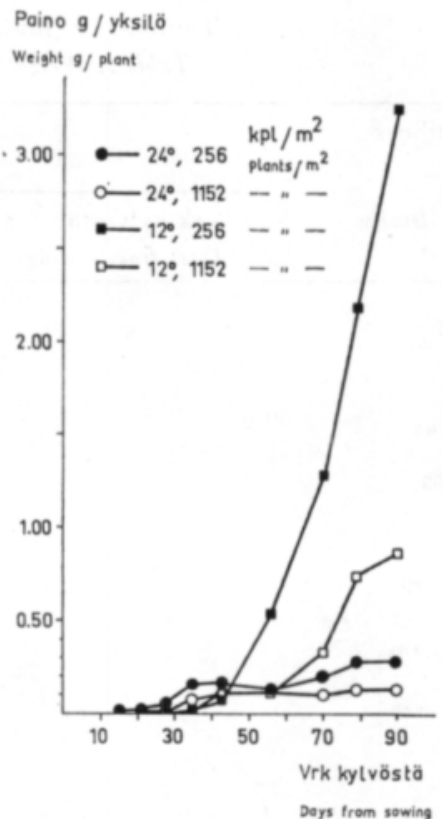

Kuva 2. Jauhosavikan yksilönpainon kehitys fytotroneissa.

Fig. 2. Weight per plant of C. album grown in phytotrons.

Astiakoehallissa juuriston paino yksilöä kohti kehittyi niinikään selvästi suuremmaksi harvassa $(0.31 \mathrm{~g}=100)$ kuin tiheässä $(48)$ kasvustossa.

Oheisesta asetelmasta ilmenee, että yksilöitten keskimääräinen $\mathrm{le} \mathrm{h}$ t i s a t o oli runsaampi harvassa kuin tiheässä kasvustossa varsinkin fytotroneissa lämpötilan ollessa $12^{\circ}$ C. Alhainen lämpötila kohotti huomattavissa määrin jauhosavikan keskimääräistä lehtisatoa yksilöä kohti:

Kasvutiheys
$100 \mathrm{kpl} / \mathrm{m}^{2}$
256
$1152 \quad$,

$\begin{array}{cc}24^{\circ} \mathrm{C} & 12^{\circ} \mathrm{C} \\ 30 \mathrm{mg}= & - \\ 100 & 2133 \\ 70 & 600\end{array}$

Astiakoehalli $740 \mathrm{mg}=100$

600

Fytotroneissa jauhosavikkayksilöitten $\mathrm{k}$ o k o n a is p a i n o oli keskimäärin pienempi tiheässä $\left(0.22 \mathrm{~g}^{*}\right)$ kuin harvassa $(0.74 \mathrm{~g})$ kasvustossa. Kasvit jäivät myös pienemmiksi $24^{\circ} \mathrm{C}$ :ssa kuin $12^{\circ} \mathrm{C}$ :ssa samalla kehitysasteella ollessaan. Oheisista suhdeluvuista ilmenevät yksilönpainot jauhosavikan kukinta-asteella:

$\begin{array}{crr}\text { Kasvutiheys } & 24^{\circ} \mathrm{C} & 12^{\circ} \mathrm{C} \\ 256 \mathrm{kpl} / \mathrm{m}^{2} & 0.16 \mathrm{~g}=100 & 2025 \\ 1152 " & 69 & 580\end{array}$

Kun kylvöstä oli kulunut 56 vuorokautta, astiakoehallissa näytti jauhosavikkayksilöitten kokonaispaino astiakoehallissa olevan jo jonkin verran korkeampi harvassa kuin tiheäs- 
Taulukko 4. Jauhosavikan yksilönpainot astiakoehallissa.

Table 4. Weights per plant of C. album grown in coolhouse.

\begin{tabular}{lllllll}
\hline $\begin{array}{l}\text { Kasvutiheys } \\
\mathrm{kpl} / \mathrm{m}^{2}\end{array}$ & \multicolumn{5}{c}{$\begin{array}{c}\text { Paino g/yksilö } \\
\text { Weight g/plant }\end{array}$} \\
\cline { 2 - 7 } $\begin{array}{l}\text { Growth density } \\
\text { plants } / \mathrm{m}^{2}\end{array}$ & $\begin{array}{l}\text { Vrk kylvöstä } \\
\text { Days from sowing }\end{array}$ & 40 & 56 & 67 & 88 & 116 \\
\hline 100 & & 0.22 & 2.37 & 5.81 & 6.79 & 7.35 \\
256 & & 0.25 & 1.68 & 3.21 & 3.61 & 3.62 \\
$\mathrm{PME}_{\mathbf{0 . 0 5}}$ & $2.00 \mathrm{~g}$ & & & & & \\
$\mathrm{LSD}_{\mathbf{0 . 0 5}}$ & & & & & &
\end{tabular}

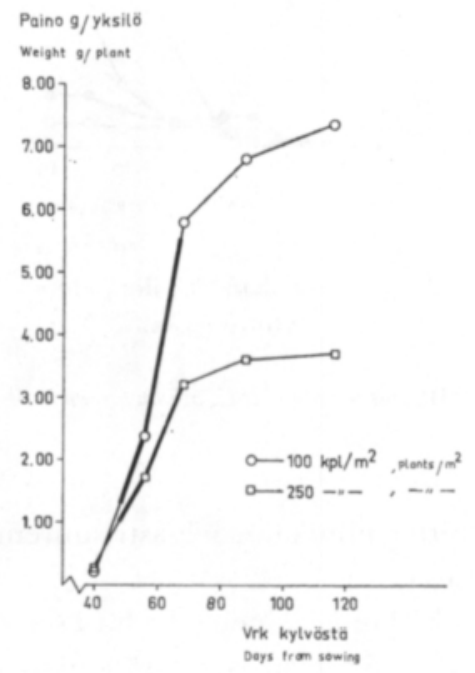

Kuva 3. Jauhosavikan yksilönpainon kehitys astiakoehallissa. Kukinnan ajankohta on merkitty kuvaajiin paksunnoksella.

Fig. 3. Weight per plant of C. album grown in coolhouse. Heavy line indicates the date of flowering.

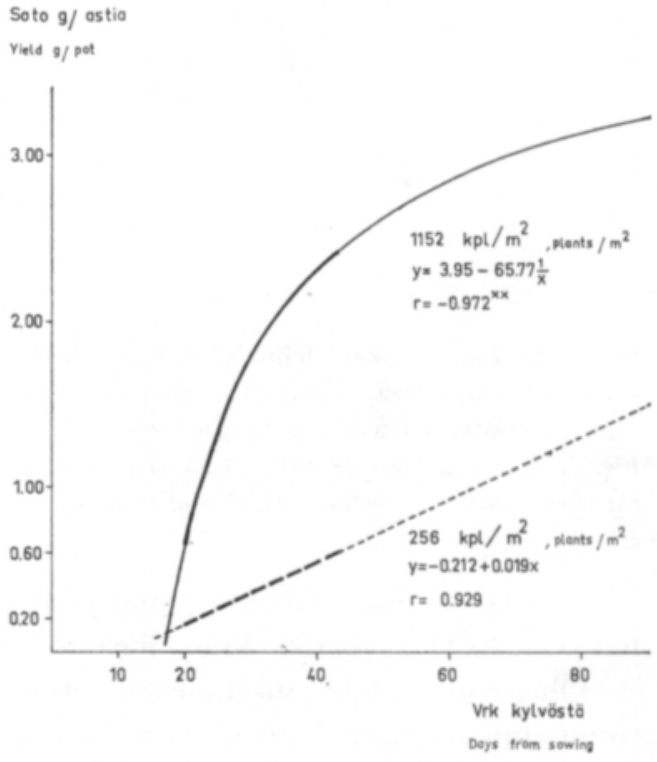

Kuva 4. Jauhosavikan sadon kehittyminen fytotronissa $24^{\circ} \mathrm{C}$ :ssa. Kukinnan ajankohta on merkitty kuvaajiin paksunnoksella.

Fig. 4. Yield of C. album grown in phytotron at $24^{\circ} \mathrm{C}$. Heavy line indicates the date of flowering.

sä kasvustossa. Ero kävi yhä selvemmäksi ja tilastollisesti luotettavaksi kasvukauden edistyessä (taulukko 4).

K o k o n a is s a to. Tiheä jauhosavikkokasvusto tuotti pinta-alayksikköä kohti harvaa runsaamman kuiva-ainesadon molemmissa kokeissa (kuvat 4 -6). Fytotroneissa jauhosavikan keskimääräinen kuiva-ainesato astiaa kohti oli merkitsevästi suurempi $12^{\circ} \mathrm{C}$ :ssa (4.62 $\left.\mathrm{g}^{*}\right)$ kuin $24^{\circ} \mathrm{C}: s s a(1.33 \mathrm{~g})$. Satokäyrän muotoon vaikuttivat huomattavassa määrin kasvuston tiheys ja lämpötila. Sato nousi $24^{\circ} \mathrm{C}$ :ssa lineaarisesti kasvien tuleentumiseen saakka, kun jauhosavikoita oli $256 \mathrm{kpl} / \mathrm{m}^{2}$ (kuva 4). Sen sijaan tiheässä kasvustossa samassa lämpötilassa satokäyrää kuvasi parhaiten funktio $y=a+b \frac{1}{x}$. Sato nousi tällöin jyrkästi verso- ja kukinta-asteella. Kukinnan loppupuolella lajinsisäisen kilpailun kasvua rajoitta- 
va vaikutus alkoi tuntua yhä selvempänä ja sadonlisäys hidastui, joskin sato nousi koko kokeen kestoajan. Sadon kehittymistä $12^{\circ} \mathrm{C}$ :ssa kuvasi etsityistä matemaattisista malleista parhaiten funktio $\log \mathrm{y}=\mathrm{a}+\mathrm{bx}+\mathrm{cx}^{2}$ (kuva 5) kummassakin tiheydessä. Tällöin sadon lisääntyminen oli kasvun alkuvaiheessa hidasta. Vasta, kun jauhosavikoissa oli $4-8$ lehteä ja ensimmäiset haarat alkoivat muodostua, muuttui sadon nousu erittäin jyrkäksi. Kun koe lopetettiin 90 vuorokauden kuluttua kylvöstä, jauhosavikka oli kukinta-asteella, eikä sadon nousu ollut hidastunut tiheässäkään kasvustossa.

Astiakoehallissa jauhosavikan kokonaissato nousi jyrkästi, kunnes kasvien kukinta päättyi ja siemenet alkoivat muodostua. Sen jälkeen painonlisäys hidastui, eivätkä satoerot kehitysasteiden välillä olleet enää tilastollisesti merkitseviä siementen kehittymisvaiheesta (=67 vrk kylvöstä) eteenpäin (kuva 6$)$.

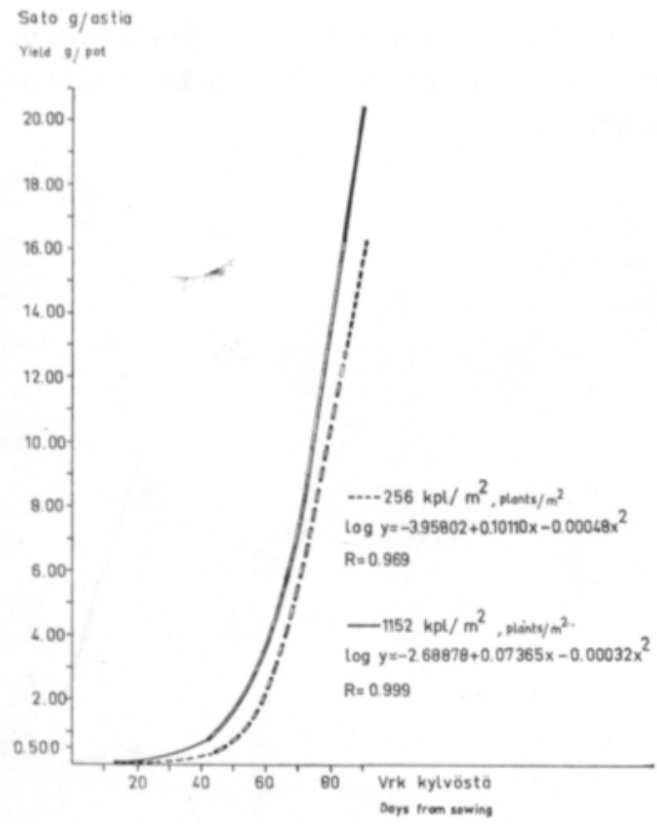

Kuva 5. Jauhosavikan sadon kehittyminen fytotronissa $12^{\circ} \mathrm{C}: s s a$. Haarojen ja nuppujen muodostumisen ajankohta on merkitty kuvaajiin vaalealla, kukinta tummalla paksunnoksella.

Fig. 5. rield of C. album grown in phytotron at $12^{\circ} \mathrm{C}$. White heavy line indicates the date of branching and flower buds, black heavy line the date of flowering.

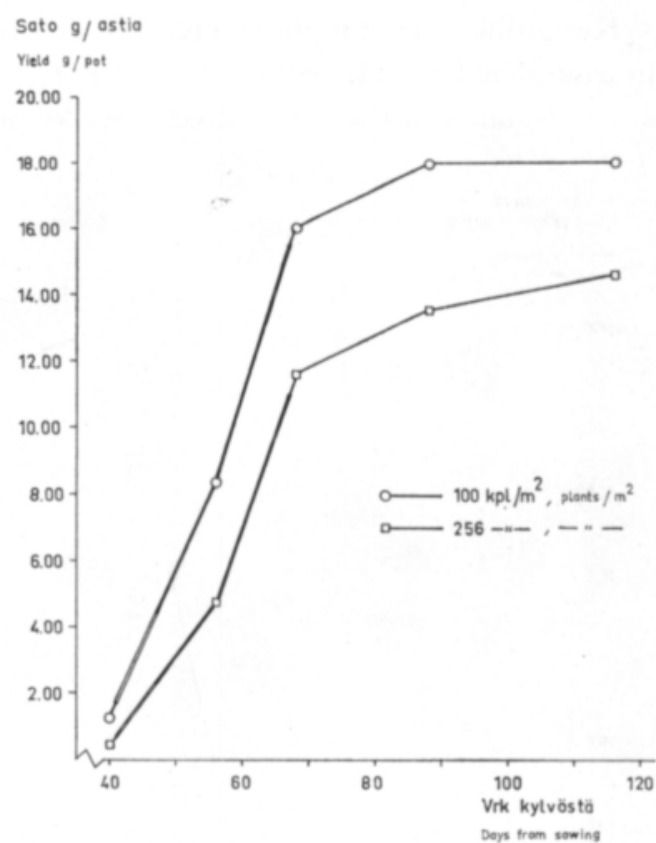

Kuva 6. Jauhosavikan sadon kehittyminen astiakoehallissa. Nuppujen muodostumisen ajankohta on merkitty kuvaajiin vaalealla, kukinta tummalla paksunnoksella.

Fig. 6. Yield of C. album grown in coolhouse. White heavy line indicates the date of flower buds, black heavy line the date of flowering.

Juurien, varsien ja lehtien osuudet. Kasvuston tiheys ei kummassakaan kokeessa vaikuttanut merkitsevästi juuri-, varsi- ja lehtisatojen prosenttisiin osuuksiin kokonaissadosta. Fytotroneissa olivat juurien ja lehtien keskimääräiset osuudet sadosta pienemmät, varsien vastaavasti suuremmat $24^{\circ}$ kuin $12^{\circ} \mathrm{C}$ :ssa: 


$\begin{array}{lcl} & 24^{\circ} \mathrm{C} & 12^{\circ} \mathrm{C} \\ \text { Juuria } \% & 5.1^{* * *} & 15.3 \\ \text { Varsia } \%{ }^{1} & 70.7^{* * *} & 29.6 \\ \text { Lehtiä } \% & 24.2^{* * *} & 55.1\end{array}$

${ }^{1}$ Sisältää myös siemensadon $24^{\circ} \mathrm{C}: s s a$.

Astiakoehallissa kokonaissato jakautui keskimäärin seuraavasti:

$\begin{array}{lr}\text { Juuria \% } & 8.7 \\ \text { Varsia ja siemeniä \% } & 60.8 \\ \text { Lehtiä \% } & 30.5\end{array}$

Jauhosavikan juurisadon osuudessa ilmeni fytotroneissa vain satunnaisia vaihteluja eri kehitysasteilla. Sen sijaan astiakoehallissa juurten ja lehtien osuus sadosta aleni versoasteelta lähtien kasvien vanhetessa.

Kasvutiheys ja lämpötila eivät aiheuttaneet merkitseviä muutoksia kasvien lehti- ja juurisatojen keskinäisessä suhteessa. Fytotroneissa se oli kukinnan alkaessa keskimäärin $4.3 \mathrm{ja}$ astiakoehallissa koko koeaikana keskimäärin 3.0.
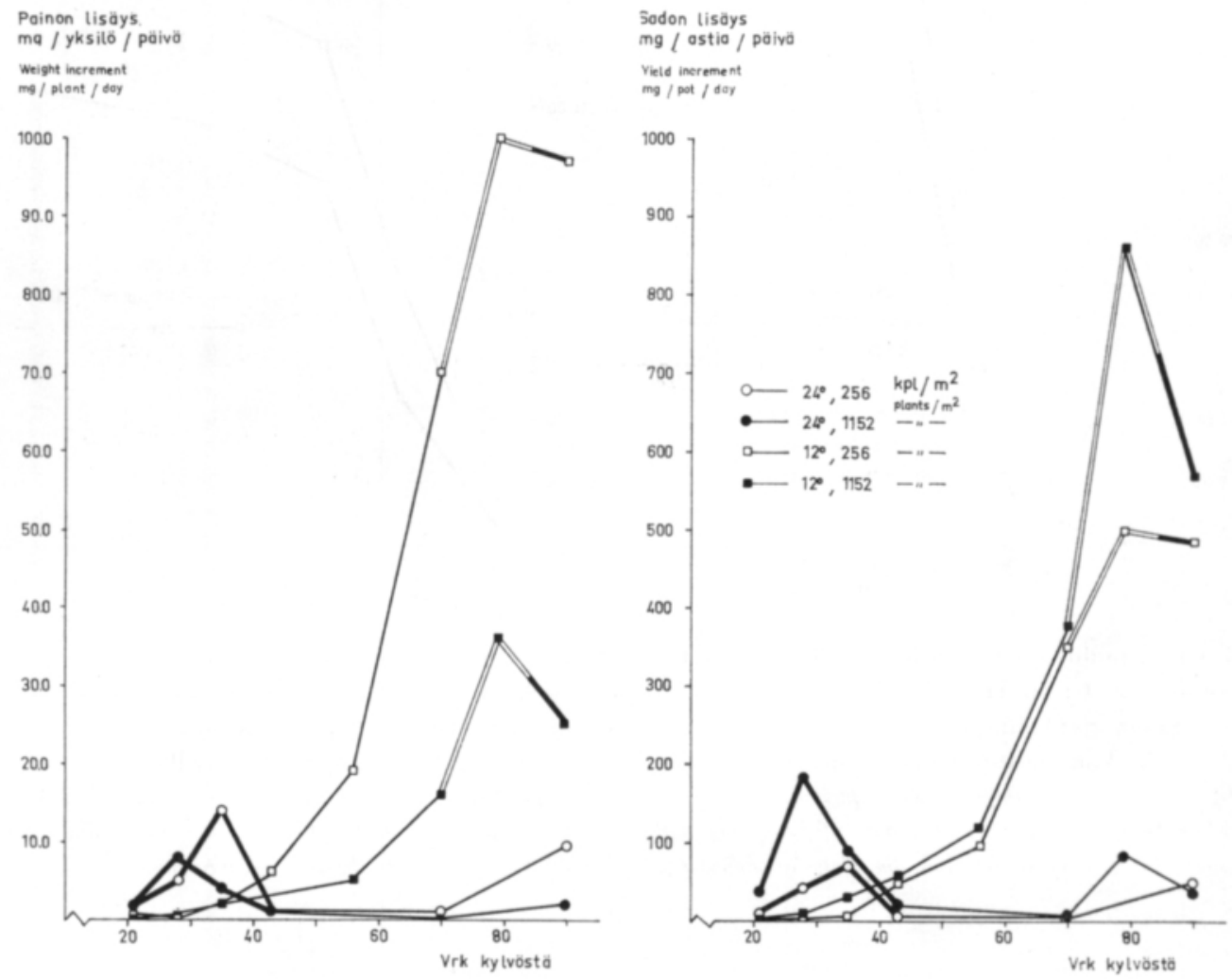

Deys trom sowing

Kuva 7. Jauhosavikan päivittäiset painonlisäykset fytotroneissa. Nuppujen muodostumisen ajankohta on merkitty kuvaajiin vaalealla, kukinta tummalla paksunnoksella.

Fig. 7. Daily weight increments of C. album grown in phytotrons. White heavy line indicates the date of flower buds, black heavy line the date of flowering. 

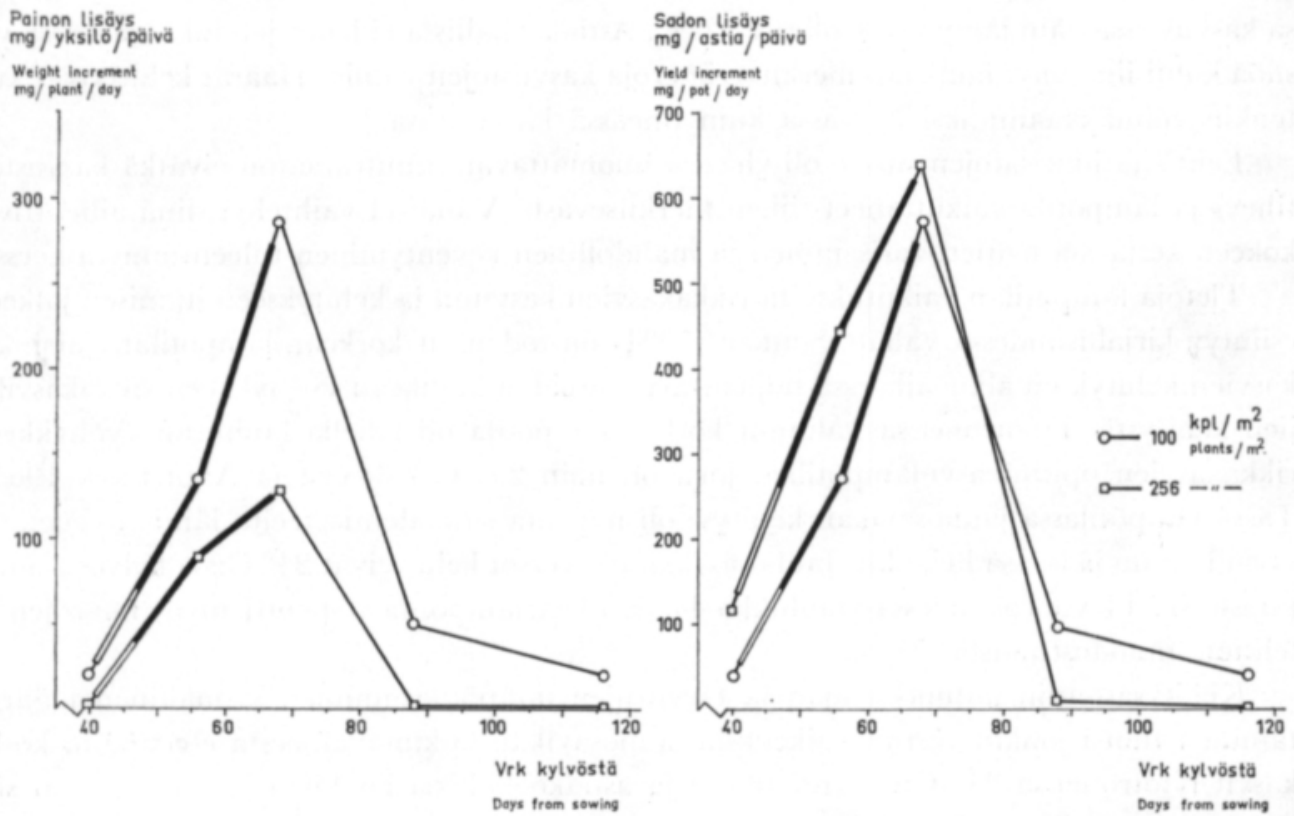

Kuva 8. Jauhosavikan päivittäiset painonlisäykset astiakoehallissa. Nuppujen muodostumisen ajankohta on merkitty kuvaajiin vaalealla, kukinta tummalla paksunnoksella.

Fig. 8. Daily weight increments of C. album grown in coolhouse. White heavy line indicates the date of flower buds, black heavy line the date of flowering.

S a d on k a svu n o peus. Päivittäinen sadonlisäys yksilöä kohti oli molemmissa kokeissa suurempi harvassa kuin tiheässä kasvustossa. Sadonlisäys pinta-alayksikköä kohti oli fytotroneissa suurempi tiheässä kuin harvassa kasvustossa. Astiakoehallissa se oli kukinnan päättymiseen saakka jonkin verran suurempi, kasvien tuleentumisvaiheessa taas pienempi tiheässä kuin harvassa kasvustossa.

Päivittäinen sadonlisäys oli fytotroneissa $24^{\circ}$ C:ssa voimakkaimmillaan jauhosavikan kukkiessa (kuva 7). Kun kukinta oli lopullaan ja siemenet alkoivat kehittyä, pieneni painonlisäys jyrkästi. Alhaisessa lämpötilassa $\left(12^{\circ} \mathrm{C}\right)$ sadonlisäys kasvoi versoasteella ja kukintojen kehittyessä, mutta alkoi vähentyä jo muutamia päiviä ennen kukintaa. Astiakoehallissa päivittäinen sadonlisäys suureni voimakkaasti nuppujen muodostumisesta kukinnan päättymiseen saakka (kuva 8). Sen jälkeen painonlisäys pieneni erittäin jyrkästi kasvien kellastumiseen asti.

\section{Tulosten tarkastelu}

Kasvuston tiheys vaikutti jauhosavikkaan tässä tutkimuksessa osittain samalla tavalla kuin ulkomaisessa kirjallisuudessa (Willıams 1964) ja kasvinviljelytieteen laitoksella aikaisemmin suoritetuissa kenttäkokeissa (ERvı̈ 1971) on todettu. Kasvuston tihentyessä yksilöitten paino ja lehtipinta-ala pienenivät (asetelma s. 33, taulukko 3). Sen sijaan lehtialaindeksi kehittyi fytotronikokeissa suuremmaksi tiheässä kuin harvassa kasvustossa (taulukko 3), kun se kenttäkokeissa vastaavissa tiheyksissä oli lähes samansuuruinen (ERvıö 1971). Myös haarojen lukumäärään kasvutiheys vaikutti po. astiakokeissa toisin kuin kenttäkokeissa. Yksilöihin kehittyi fytotroneissa vähemmän haaroja tiheässä kuin harvas- 
sa kasvustossa vain lämpötilan ollessa $12^{\circ} \mathrm{C}$. Astiakoehallissa ei haarojen lukumäärässä yksilöä kohti ilmennyt lainkaan merkitseviä eroja kasvustojen välillä. Haarat kehittyivät kuitenkin voimakkaammiksi harvassa kuin tiheässä kasvustossa.

Lehti- ja juurisatojen suhde oli yleensä huomattavan muuttumaton eivätkä kasvuston tiheys ja lämpötila vaikuttaneet siihen merkitsevästi. Vähäistä vaihtelua siinä aiheuttivat kokeen kestäessä lehtien variseminen ja mahdollinen keventyminen tuleentumisvaiheessa.

Tietoja lämpötilan vaikutuksesta rikkakasvien kasvuun ja kehitykseen itämisen jälkeen esiintyy kirjallisuudessa vähän. ScHeER (1934) on todennut korkean lämpötilan varsinkin kasvien kehityksen alkuvaiheessa nopeuttavan useiden lauhkean vyöhykkeen rikkakasvilajien kehitystä. Fytotroneissa valinnut korkea lämpötila oli lähellä lauhkean vyöhykkeen rikkakasvien optimikasvulämpötilaa, joka on noin $25^{\circ} \mathrm{C}$ (Meyer ja ANDERsson 1963). Tässä lämpötilassa jauhosavikan kehitys oli nopeata sirkkalehtiasteelta lähtien vegetatiivisen kasvun jäädessä heikoksi. Jauhosavikan pääversot kehittyivät $24^{\circ} \mathrm{C}$ :ssa kylvöstä nuppuasteelle 14 vuorokaudessa (taulukko 1). Korkea lämpötila nopeutti myös haarojen ja lehtien muodostumista.

Kehitysasteisiin kuluneen ajan ja tarvittujen lämpötilasummien täsmällinen määrittäminen tuotti jonkin verran vaikeuksia jauhosavikan kukintavaiheesta eteenpäin, koska kasvit fytotroneissa $24^{\circ}$ C:n lämpötilassa ja astiakoehallissa kukkivat ja muodostivat siemeniä samanaikaisesti.

Jauhosavikan kehitysnopeus samoin kuin lämpötilasummat olivat erilaiset $12^{\circ}$ kuin $24^{\circ}$ C:ssa (taulukko 1). Alkukehityksen aikana haarojen muodostumiseen saakka lämpötilasummat poikkesivat toisistaan vain vähän, mutta nuppuasteeseen ja kukinnan alkamiseen jauhosavikka tarvitsi $12^{\circ} \mathrm{C}$ :ssa yli kaksinkertaisen lämpötilasumman $24^{\circ} \mathrm{C}$ :een verrattuna. Juuri näissä kehitysvaiheissa $12^{\circ} \mathrm{C}$ :n lämpötilassa tapahtui voimakas vegetatiivinen kasvu (kuva 5), johon kasvit käyttivät energiaa.

Vaikka jauhosavikka kehittyi nopeammin $24^{\circ}$ kuin $12^{\circ} \mathrm{C}$ :ssa, jäi kasvien sato yksilöä kohti pienemmäksi korkeassa kuin alhaisessa lämpötilassa (asetelmat s. 33) päivittäisen sadonlisäyksen ollessa kokeen aikana $24^{\circ} \mathrm{C}$ :ssa keskimäärin $2 \mathrm{mg}$ ja $12^{\circ} \mathrm{C}$ :ssa $23 \mathrm{mg}$ yksilöä kohti. Tämä on osaksi saattanut johtua valaistuksen ja lämpötilan suhteesta, joka $24^{\circ} \mathrm{C}$ :ssa ei ehkä ollut kasvulle optimaalinen. Lämpötilaan nähden heikon valon intensiteetin on nimittäin todettu pienentävän kasvien kuiva-ainesatoa (WENT 1957, NösBERger 1971). Viileän yölämpötilan puuttuminen on myös osaltaan voinut vaikuttaa sadon määrään $24^{\circ}$ C:ssa, sillä eräiden tutkimusten mukaan (CLAusEN ym. 1948) viileään ilmastoon tottuneet kasvit kasvavat paremmin, kun yölämpötila on huomattavasti päivälämpötilaa $\left(20-30^{\circ} \mathrm{C}\right)$ alhaisempi.

Fytotronikokeiden harva kasvusto oli tiheydeltään lähes puolet keskimääräisestä rikkakasvien runsaudesta sellaisilla kevätviljamaillamme, joilla torjuntaa ei ole suoritettu (Mukula ym. 1969). Yksilöitten vegetatiivisen kasvun jäädessä $24^{\circ} \mathrm{C}$ :ssa heikoksi ei tässä kasvustossa syntynyt voimakasta kilpailua kokeen aikana, koska sato nousi lineaarisesti jauhosavikan tuleentumiseen asti (kuva 4). Kun kasveja oli samoissa oloissa $1152 \mathrm{kpl} / \mathrm{m}^{2}$ vastaava määrä, sato nousi aluksi jyrkästi, kunnes yksilöitten keskinäinen kilpailu alkoi rajoittaa kasvua ja sadon nousu hidastui kukinnan loppupuolella kuitenkaan kokonaan lakkaamatta. Päivittäinen sadon lisääntyminen yksilöä kohti osoittaa kuitenkin, ettei yksilöitten välinen kilpailu tässäkään kasvustossa muodostunut erityisen ankaraksi, koska keskimääräinen sadonlisäys kokeen aikana oli sama kuin harvassakin kasvustossa, 2 mg yksi- 
löä kohti. Fytotronikokeissa käytetty $12^{\circ} \mathrm{C}:$ lämpötila oli suunnilleen samansuuruinen kuin toukokuun lopun ja kesäkuun alkupäivien keskilämpötila Etelä-Suomessa, joskaan se vaikutukseltaan kasveihin ei täysin vastaa tuota ajankohtaa korkeampien päivälämpötilojen ja alhaisempien yölämpötilojen puuttuessa. Kasvien alkukehitys oli tällöin hidasta sirkkalehtiasteelta haarojen muodostumiseen saakka. Sitä seurasi voimakkaan vegetatiivisen kasvun kausi, jolloin kasvit rehevöityivät. Rehevästä kasvusta johtuneen kilpailun voimakkuutta näissä kasvustoissa kuvastaa kokeen aikana tapahtunut yksilöitten päivittäinen painonlisäys joka oli harvassa kasvustossa keskimäärin $36 \mathrm{mg}$, mutta tiheässä vain 10 mg yksilöä kohti. Kilpailun vaikutuksesta olisi sadon nousu oletettavasti jossakin kehitysvaiheessa hidastunut ainakin tiheässä kasvustossa, jolloin sadon kehitystä olisi kuvannut sigmoidinen kasvukäyrä (KORMONDY 1970). Kun koe kuitenkin lopetettiin kasvien ollessa $12^{\circ} \mathrm{C}$ :ssa kukinta-asteella, ei sadon nousu ehtinyt hidastua kokeen aikana, vaan satokäyrä tässä kokeessa oli kuvassa 5 esitetyn mukainen.

\section{Ti $i$ vis te $\operatorname{lm} \ddot{a}$}

Tutkimukset suoritettiin astiakokeina fytotroneissa, joissa lämpötilat olivat $24^{\circ}$ ja $12^{\circ} \mathrm{C}$, sekä astiakoehallissa. Jauhosavikan haarojen lukumäärä yksilöä kohti oli suurempi harvassa kuin tiheässä kasvustossa lämpötilan fytotroneissa ollessa $12^{\circ} \mathrm{C}$. Lehtialaindeksi (LAI) oli pienempi, lehtiala yksilöä kohti suurempi harvassa kuin tiheässä kasvustossa. Yksilöitten juuri- ja lehtisato seka kokonaispaino kehittyivät suuremmiksi harvassa kuin tiheässä kasvustossa. Kokonaissato pinta-alayksikköä kohti oli runsaampi tiheässä kuin harvassa kasvustossa. Kasvutiheys ja lämpötila vaikuttivat huomattavasti satokäyrän muotoon (kuvat 4-5). Kasvuston tiheys ei vaikuttanut merkitsevästi lehti- ja juurisatojen keskinäiseen suhteeseen. Sadon päivittäinen kasvu yksilöä kohti oli suurempi, lisäys pintaalayksikköä kohti taas pienempi harvassa kuin tiheässä kasvustossa.

Jauhosavikan vegetatiivisen kasvun aika lyheni ja kehitys nopeutui $24^{\circ}$ C:n lämpötilassa. Jauhosavikan eri kehitysasteisiinsa tarvitsemat lämpötilasummat poikkesivat toisistaan $24^{\circ}$ ja $12^{\circ} \mathrm{C}$ :ssa. Kasvit tuleentuivat fytotroneissa $24^{\circ} \mathrm{C}$ :ssa 90 vuorokaudessa ja astiakoehallissa $\left(15.4^{\circ} \mathrm{C}\right) 116$ vuorokaudessa vastaavien lämpötilasummien ollessa $2160^{\circ} \mathrm{ja}$ $1837^{\circ}$. Jauhosavikan LAI ja lehtiala yksilöä kohti kehittyivät suuremmiksi $12^{\circ}$ kuin $24^{\circ}$ C:ssa. LAI oli $24^{\circ} \mathrm{C}$ :ssa suurimmillaan kasvien kukkiessa ja $12^{\circ} \mathrm{C}$ :ssa ennen kukinnan alkamista. Fytotroneissa alhainen lämpötila $\left(12^{\circ} \mathrm{C}\right)$ kohotti juurien ja lehtien painoa sekä kokonaispainoa yksilöä kohti kasvien ollessa samalla kehitysasteella. Juurien ja lehtien osuus sadosta muodostui pienemmäksi, varsien vastaavasti suuremmaksi $24^{\circ}$ kuin $12^{\circ} \mathrm{C}$ :ssa. Lämpötila ei vaikuttanut merkitsevästi lehti- ja juurisatojen keskinäiseen suhteeseen. Lämpötilan ollessa $12^{\circ} \mathrm{C}$ sadon voimakkain päivittäinen kasvu tapahtui varhaisemmalla kehitysasteella kuin $15.4^{\circ}$ (astiakoehalli) ja $24^{\circ} \mathrm{C}$ :ssa.

\section{KIRJALLISUUTTA}

Barton, L. V. 1953. Dormancy in seeds. Rep. 13th Int. hort. Congr. Lond. 1952, 2:1001-1012.

Clanusen, J., Keck, D. D. \& Hiesey, W. M. 1948. Experimental studies on the nature of species. III. Environmental responses of climatic races of Achillea. Carnegie Inst. Wash., Publ. 520: 1-129. 
ERviö, L-R. 1971. The effect of intra-specific competition on the development of Chenopodium album L. Weed Res. 11:124-134.

Hull, H. 1958. The effect of day and night temperature on growth, foliar wax content and cuticle development of velvet mesquite. Weeds 6:133-141.

Häkansson, S. 1969. Experiments with Agropyron repens (L.) Beauv. 7. Temperature and light effects upon development and growth. Lantbr. Högsk. Ann. 35: 953-987.

Jordan, L. \& DAy, B. 1967. Effect of temperature on growth of Oxalis cernua Thund. Weeds 15: 285.

KoLK, H. 1947. Groningsbiologiska studier på ogräsarter. Växtodling 2:108-167.

Kormondy, E. J. 1971. Ekologia. 205 p. (Suom. P. BorG). Jyväskylä.

Meyer, B. \& Anderson, P. 1963. Plant Physiol. 784 p. New York.

Mukula, J., Raatikainen, M., Lallukka, R. \& Raatikainen, T. 1969. Composition of weed flora in spring cereals in Finland. Ann. Agric. Fenn. 8:59-109.

NösBerger, J. 1971. Einfluss der Bestandeshichte auf die Ertragsbildung bei Mais. Z. Acker-, Pfl.bau 133:215-232.

SCHEER, W. 1934. Vergleichende Untersuchungen über den Entwicklungsrhytmus verschiedener Unkraut-Arten in seiner Abhängigkeit von der Witterung und in seiner Beziehung zu dem der Deckfrüchte. Arb. biol. Reichsanst. Land. Forstw. 21:153-196.

Steinbauer, G. P. \& Grigsby, B. 1957. Interaction of temperature, light and moistening agent in the germination of weed seeds. Weeds 5:175-182.

Williams, J. T. 1964. A study of the competitive ability of Chenopodium album. Interference between kale and C. album in pure stands and in mixtures. Weed Res. 4: 283-295.

WENT, F. W. 1957. The experimental control of plant growth. 343 p. Waltham. 